\title{
Struktura opskrbnog lanca jabuka i analiza odnosa između članova lanca
}

\section{Sažetak}

Cilj ovog rada bio je utvrditi strukturu i stanje u opskrbnim lancima jabuka, te analizirati odnose između članova lanca. Anketno istraživanje provedeno je na uzorku od 50 proizvođača i 10 otkupljivača (distributera) jabuka. Rezultati istraživanja su pokazali da proizvođači jabuke plasiraju na tržište putem izravnih i neizravnih kanala prodaje. Izravna prodaja krajnjem potrošaču vrši se prodajom na gospodarstvu i dostavom na kućni prag dok neizravni kanali prodaje uključuju prodaju jabuka voćarnama i distributerima. Jabuka iz malih privatnih voćarni dolazi izravno do kupca, dok se jabuka iz distribucijskih centara plasira preko gradskih tržnica, malih prodavaonica u susjedstvu i trgovačkih lanaca do krajnjeg kupca. Analizirajući ukupnu suradnju između članova opskrbnog lanca utvrđeno je da su međusobnim odnosima najzadovoljniji proizvođači, a najmanji stupanj zadovoljstva utvrđen je u odnosu između otkupljivača (distributera) $i$ trgovaca. Najčešći problemi s kojim se proizvođači susreću prilikom prodaje jabuka su niska otkupna cijena, način plaćanja, te nepoštivanje rokova plaćanja, dok otkupljivači (distributeri) kao najčešće probleme u odnosu s proizvođačima navode nepoštivanje rokova isporuke i kvalitetu jabuka, te poštivanje dogovora. Kod prodaje jabuka trgovcima distributeri kao najvažnije probleme u poslovanju izdvajaju dogovor oko postizanja prihvatljive prodajne cijene te previsoke standarde kvalitete jabuka pri otkupu. Prema nalazima istraživanja moguće je zaključiti da postoje značajne razlike u percepciji odnosa proizvođača i tržnih posrednika u opskrbnom lancu jabuka. Kako bi povećali uspješnost opskrbnih lanaca jabuka potrebno je: (1) poslovati u skladu s zakonom u kojem su definirani rokovi ispunjenja novčanih obveza, (2) zakonski regulirati nepoštene trgovačke prakse (eksploatacijski ugovori, visoki rabati, kratki rokovi isporuke, povrat neprodane robe), (3) poboljšati komunikaciju i razvijati partnerske odnose temeljene na povjerenju. Rezultati istraživanja mogu poslužiti kao informativna podloga istraživačima u području upravljanja op skrbnim lancima prehrambenih proizvoda te svim ispitanicima čije su tvrtke sudjelovale u istraživanju na način da ih potakne da na temelju utvrđenog stanja poduzmu određene mjere za poboljšanje uspješnosti opskrbnih lanaca kojima pripadaju.
\end{abstract}

Ključne riječi: tržište jabuka, Hrvatska, opskrbni lanac, poslovni odnosi

\section{Uvod}

Po obujmu proizvodnje jabuka je u svijetu, a i kod nas, najzastupljenija kontinentalna voćna vrsta. Svjetska proizvodnja jabuka u 2014. godini iznosila je 84,6 milijuna tona, čime ona u svjetskoj proizvodnji voća zauzima treće mjesto iza agruma i banana (FAO, 2016). U 2015. godini jabuka je u Hrvatskoj bila zasađena na 5.756 ha, ukupna proizvodnja iznosila je 101.750 tona, od čega je 96.182 tone bila intenzivna proizvodnja za tržište, a 5.570 tona proizvodnja u ekstenzivnim voćnjacima (pretežno za vlastite potrebe) (DZS 2016).

Potrošnja jabuka u 2015. godini u Hrvatskoj je iznosila 95.000 tona godišnje - kao konzumna i u obliku raznih prerađevina (sokovi, osušena jabuka i dr.), dok je samodostatnost tržišta jabuka iznosila 107\%. Zahvaljujući suvremenim tehničkim rješenjima u čuvanju jabuke (ULO hladnjače), danas potrošnja svježih plodova jabuke traje čitave godine, i to od lipnja kada počinju dozrijevati rane ljetne sorte, pa sve do idućeg ljeta kada se vade iz hladnjače kasne zimske sorte. Kvaliteta jabuka na domaćem tržištu najčešće se ocjenjuje kao osrednja. Najzastupljenije i najprodavanije sorte jabuka u Hrvatskoj su Idared, Zlatni Delišes, Jonagold, Granny Smith, Gloster od zimskih (jesenskih) sorata, a od ljetnih sorti

Doc.dr.sc. Željka Mesić, Ana Jezidžić, mag.ing.agr, Dr.sc. Marina Tomić, Doc.dr.sc. Lari Hadelan,

Sveučilište u Zagrebu Agronomski fakultet, Svetošimunska cesta 25, 1000 Zagreb kontakt: telefon: +385 012393641 e-mail: zmesic@agr.hr 
Gala i Elstar (Krpina i sur., 2004). Osim u svježem stanju, jabuke se troše i u prehrambenoj industriji u proizvodnji džemova, marmelada, sokova i dehidriranih proizvoda (Woodroof i Luh, 1975). Cijene takve jabuke i nekoliko puta su niže od onih koje se postižu za konzumnu jabuku iz suvremenih hladnjača, a osobito u zimskom i proljetnom razdoblju kada na tržištu nedostaje svježeg voća. Stoga je imperativ u suvremenoj proizvodnji jabuka, s obzirom na visoke troškove proizvodnje, što veći udio prvoklasnih plodova koji mogu zadovoljiti zahtjeve sve izbirljivijih kupaca. Tržište voća u Hrvatskoj, pa tako i tržište jabuka, je neorganizirano i nedovoljno razvijeno, a brojni mali proizvođači uključeni u opskrbni lanac jabuke ${ }^{3}$ nisu dobro organizirani i povezani (Par i sur., 2009). Opskrbni lanci su mreže međusobno povezanih gospodarskih subjekata koji uzajamno i u suradnji kontroliraju, upravljaju i poboljšavaju tijek proizvoda od dobavljača do krajnjeg korisnika (Bozarth i Handfield, 2006; Christopher, 2005). Opskrbni lanci formiraju organizacije odgovorne za proizvodnju (poljoprivrednici), distribuciju, preradu i prodaju poljoprivrednih proizvoda do krajnjih potrošača (Boudahri i sur., 2011; Bourlakis i Weightman, 2004). Za razliku od opskrbnih lanaca u industriji, prema Fischeru i Hartman (2010) opskrbni lanci poljoprivredno - prehrambenih proizvoda pokazuju sljedeće značajke:

1. Poslovni odnosi unutar opskrbnog lanca obično se konfrontiraju na podjeli profita (profit-rabat odnos). Takva situacija je u pravilu "win-lose" odnos budući da kad jedna strana ostvari veći rabat, drugoj se izravno smanjuje profit. Ovi odnosi su posljedica nepovjerenja između članova lanca.

2. Poljoprivredni proizvođači se najčešće tretiraju kao zamjenjivi (i iskoristivi) ulazni dobavljači. Oni često rade na ograničenim tržištima ili pod kratkoročnim ugovorima te je i veći rizik na njihovoj strani.

3. Dobit od prodaje finalnih prehrambenih proizvoda je neravnomjerno raspoređena duž opskrbnog lanca jer prerađivači i trgovci obično ostvaruju značajno veći udio zarade u odnosu na proizvođače sirovine.

Današnji opskrbni lanac jabuka, gledano organizacijski, karakteriziraju sljedeće faze: proizvodnja, pakiranje, skladištenje, transport, distribucijski centri, priručna skladišta i prodajne police (prilagođeno prema Prester, 2012). Aktivnosti opskrbnog lanca započinju narudžbom kupca, a završavaju kada zadovoljni kupac plati isporučenu robu na osnovu ispostavljenog računa (Pupavac, 2010). Opskrbni lanci pored pouzdanosti isporuke, ažurnosti isporuke i razvijanja čvrstih partnerskih veza, moraju odgovoriti i zahtjevima fleksibilnosti i adaptiranosti (Prester, 2012). Sve kraći životni vijek proizvoda i sve brže tehnološke promjene zahtijevaju da opskrbni lanci rade po načelu "predvidi i odradi", nasuprot tradicionalnom pristupu "proizvedi pa prodaj". Određivanjem kupca kao početne točke opskrbnog lanca nameće se sasvim novi pristup upravljanja opskrbnim lancima koji bi se umjesto opskrbnim lancem mogao nazvati lanac potražnje (Pupavac, 2010).

Jedan od preduvjeta uspješnog funkcioniranja opskrbnih lanaca su kvalitetni poslovni odnosi među članovima opskrbnog lanca (Gellynck $i$ sur., 2008; Benton i Maloni, 2005; Sahay, 2003). Prethodna empirijska istraživanja su pokazala da su suradnja i partnerstvo među članovima opskrbnog lanca jedan od preduvjeta uspješnog funkcioniranja opskrb- 
nih lanaca (Mburu, 2012; Bonaventure, 2011; Molnár i sur., 2011; Fischer i sur., 2008; Benton i Maloni, 2005; Mentzer i sur., 2001). Ukoliko se uspješna suradnja uspostavi u cijelom opskrbnom lancu, njezini učinci su puno veći od učinaka koje daje "suradnja parova" (između samo dvaju članova opskrbnog lanca) te ti opskrbni lanci u cjelini (kao i svi gospodarski subjekti pojedinačno) postaju konkurentniji na tržištima na kojima posluju (Duleba, 2008). Prema Prester (2012) bolja povezanost i komunikacija između članova opskrbnog lanca rezultira boljim prognoziranjem potražnje za sve članove, ubrzanjem toka proizvoda i usluga te podizanjem kvalitete cjelokupne distribucije i proizvodnje. Zbog svega navedenog pri analizi opskrbnih lanaca važno je uzeti u obzir i odnose među članovima kao važnu determinantu njihove uspješnosti.

Unatoč potrebi realnog sektora da se poveća učinkovitost distribucije u Hrvatskoj do sada nije provedeno ni jedno istraživanje o funkcioniranju opskrbnih lanaca jabuka.

Zbog toga će se u okviru ovog istraživanja utvrditi struktura i stanje u opskrbnim lancima jabuka, te će se analizirati odnosi između članova lanca.

\section{Materijali i metode}

U prvoj fazi istraživanja, telefonski su kontaktirani proizvođači jabuka koji su za potrebe istraživanja naveli najvažnije otkupljivače jabuka (distributere). Sudionicima koji su pristali na sudjelovanje $u$ istraživanju, anketni upitnik poslan je putem elektroničke pošte. U istraživanju su korištena dva anketna upitnika: (1) anketni upitnik za proizvođače i (2) anketni upitnik za otkupljivače jabuka. Većina se pitanja u upitnicima podudarala, s time da je svaki upitnik imao i dodatna pitanja, specifična za pojedinu skupinu ispitanika. Anketni upitnici sadržavali su pitanja o strukturno-poslovnim pokazateljima poslovnih subjekata, kvaliteti poslovnih odnosa, vrsti ugovora između članova te pitanja o problemima i odnosima u opskrbnom lancu. Uzorak je bio prigodni iz dostupnih baza udruga/zadruga proizvođača jabuka. Odnosi između proizvođača i otkupljivača jabuka analizirani su pomoću četiri konstrukta: 1) Povjerenje2 , 2) Ekonomsko zadovoljstvo33, 3) Reputacija4 i 4) Konflikt $^{5}$, koji su operacionalizirani kroz 11 izjava preuzetih iz literature (Ganesan, 1994; Molnar 2011. prema Geyskens i Steenkamp, 2000; Reve i Stern, 1979). Ispitanici - članovi lanca su ocijenili stupanj suglasnosti s izjavama pomoću ljestvice od pet stupnjeva (od „uopće se ne slažem (1)“ do „u potpunosti se slažem (5)"). Svaki proizvođač jabuka prvo je ocijenio odnos s odabranim otkupljivačem jabuka (distributerom), a u sljedećoj fazi istraživanja otkupljivač (distributer) je ocijenio svoj odnos s odabranim dobavljačem (proizvođačem jabuka) i kupcem jabuka (trgovac) na temelju izjava preuzetih iz radova Geyskens i Steenkamp (2000) te Kumar i sur. (1995).

Podaci prikupljeni anketnim ispitivanjem analizirani su jednovarijatnim statističkim metodama radi opisa uzorka, u statističkom programu SPSS (Statistical Package for Social Sciences, verzija 17.0).

Povjerenje se odnosi na razinu do koje partneri smatraju jedni druge vjerodostojnima i dobronamjernima (Kumar i sur., 1995).

Ekonomsko zadovoljstvo je stupanj zadovoljstva tvrtke postignutim ekonomskim rezultatom koji proizlazi iz odnosa s njegovim partnerom u opskrbnom lancu (Geyskens i Steenkamp, 2000).

Reputacija se definira kao mjera u kojoj partneri u opskrbnom lancu vjeruju jedan drugome da su iskreni i da su poznati po brizi za svoje poslovne partnere (Ganesan, 1994).

Konflikt predstavlja ukupnu razinu neslaganja u partnerstvu opskrbnog lanca (Reve i Stern, 1979). 


\section{Rezultati i rasprava}

Struktura opskrbnog lanca jabuka buka.

$\mathrm{Na}$ temelju rezultata istraživanja na slici 1. prikazana je struktura opskrbnog lanca ja-

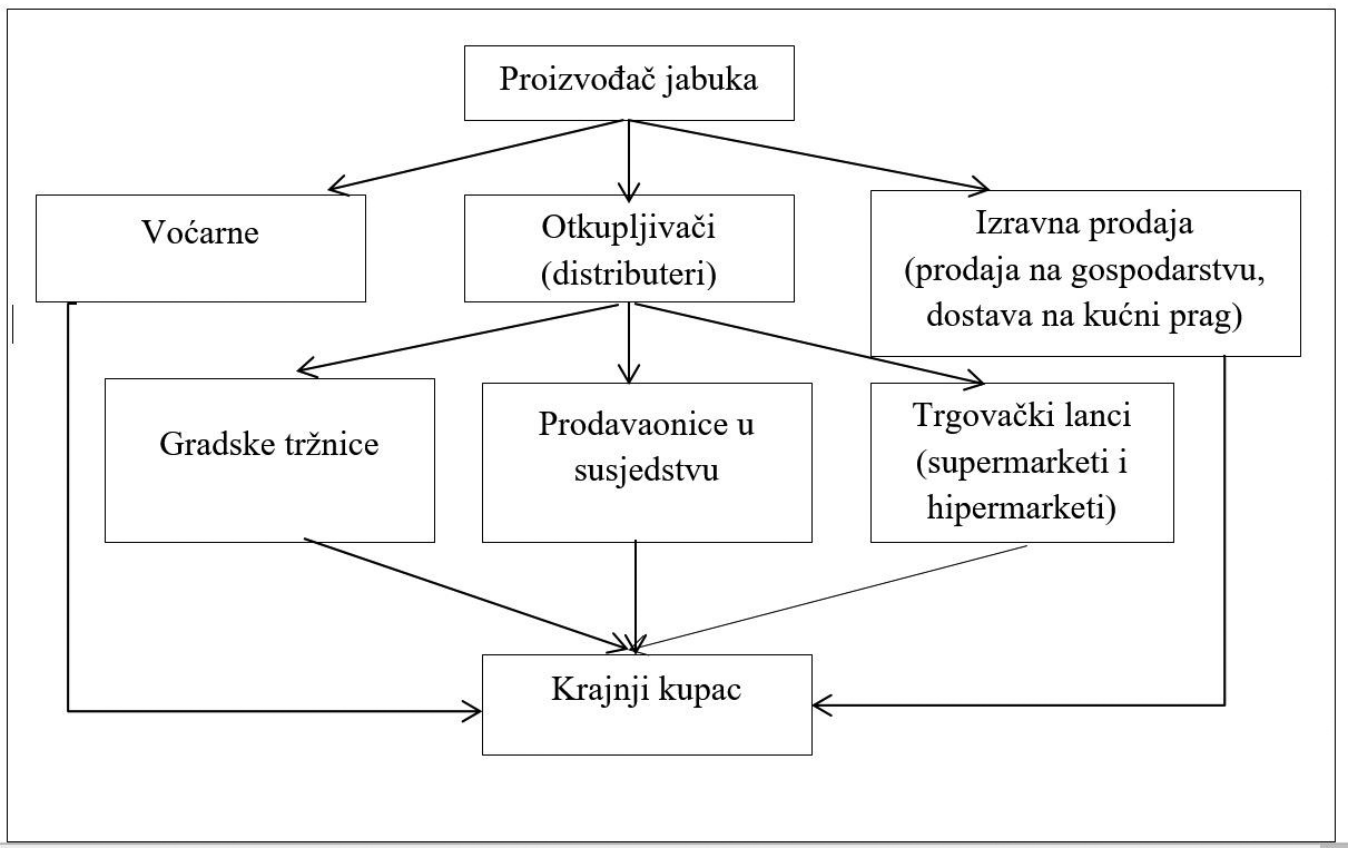

Slika 1. Struktura opskrbnog lanca jabuka

Proizvođači jabuke plasiraju na tržište putem izravnih i neizravnih kanala prodaje. Neizravni kanali uključuju male privatne voćarne i otkupljivače jabuke (distributere), a izravna prodaja krajnjem potrošaču vrši se prodajom na gospodarstvu i dostavom na kućni prag. Jabuka iz malih privatnih voćarni dolazi izravno do kupca, dok se jabuka iz distribucijskih centara plasira preko gradskih tržnica, malih prodavaonica u susjedstvu i trgovačkih lanaca (supermarketi, hipermarketi) do krajnjeg kupca. Kod prodaje preko posrednika, odnosno preko distributera opskrbni lanac jabuka je organiziran na način da nakon što distributer primi narudžbu od trgovca, vrši utovar klasirane jabuke u vozila s rashladnim uređajem te ih dostavlja na adresu trgovca. Glavni problem distributera je taj što kod većine trgovačkih lanaca distributeri moraju vršiti dostavu u svaku njihovu prodavaonicu osim ako trgovački lanac nema centralno skladište, što znatno povećava ukupne troškove distribucije.

Rezultati anketnog ispitivanja s proizvođačima jabuka

U istraživanju je sudjelovalo 50 proizvođača jabuka. Prema spolnoj strukturi, 100\% uzorka čine muškarci. Dobna struktura uzorka je donekle pomaknuta prema ispitanicima starije životne dobi; najzastupljenije dobne skupine u uzorku su od 50 do 60 godina starosti (46\%), dok je skupina iznad 60 godina zastupljena svega 4\%. Prema stupnju obrazovanja, najviše ispitanika ima završenu srednju školu (76\%), dok su preostali s visokim obrazovanjem (24\%) (Tablica 1). 
Tablica 1. Sociodemografska obilježja ispitanika

\begin{tabular}{lccc}
\hline Karakteristike & N & \% \\
\hline \multirow{2}{*}{ Spol } & Muško & 50 & 100,0 \\
\hline \multirow{2}{*}{ Dob } & $30-40$ & 10 & 20,0 \\
& $40-50$ & 15 & 30,0 \\
\hline \multirow{2}{*}{ Obrazovanje } & $50-60$ & 23 & 46,0 \\
& $60-70$ & 2 & 4,00 \\
\hline Ukupno & SSS & 38 & 76,0 \\
\hline
\end{tabular}

U najvećem postotku (92\%) ispitanici su članovi neke zadruge (Zadruga Zagrebački Voćnjaci; Poljoprivredna Zadruga Popovača) ili udruge proizvođača (Udruga vinograda, vinara i voćara Škrlet, Popovača; STELLA; D. Kraljevec). Samo osam ispitanika nisu članovi niti jednog udruženja. S obzirom na iskustvo bavljenja proizvodnjom gotovo polovica ispitanika (48\%) se proizvodnjom jabuka bavi od 15 do 20 godina, a nešto više od trećine ispitanika (36\%) od 20 do 25 godina. Najmanji se udio proizvođača (16\%) proizvodnjom bavi između 5 i 15 godina.

Proizvođači kao glavne probleme u proizvodnji jabuka ističu rizik od vremenskih nepogoda, visoku cijenu repromaterijala i ostalih inputa vezanih za proizvodnju. $\mathrm{U}$ ukupnoj prodaji jabuka, zastupljeniji su neizravni kanali prodaje u odnosu na izravne kanale prodaje. Od ukupno $84 \%$ ispitanika koji neizravno prodaju svoje proizvode, njih $72 \%$ prodaje jabuke distributerima, a $12 \%$ malim privatnim voćarnama. Svega $16 \%$ proizvođača jabuke prodaje izravno krajnjem potrošaču prodajom na gospodarstvu ili dostavom na kućni prag.

\section{Analiza odnosa proizvođača s otkupljivačima (distributerima) jabuka}

Analizom odnosa proizvođača s otkupljivačima (distributerima) jabuka utvrđeno je da svi proizvođači s otkupljivačima imaju potpisan ugovor o kupoprodaji robe kojim su definirani rokovi i način plaćanja. Način plaćanja može biti u novcu, bonovima, repromaterijalu i/ ili putem kompenzacije što u većini slučajeva proizvođačima predstavlja problem. Najčešći problemi s kojim se proizvođači susreću prilikom prodaje jabuka otkupljivačima (distributerima) su niska otkupna cijena jabuka (44\%), način plaćanja (24\%), te nepoštivanje rokova plaćanja (32\%). Proizvođači su zadovoljniji prodajnom cijenom jabuka van sezone (srednja ocjena 3,66) u odnosu na cijenu jabuka u sezoni (srednja ocjena 3,24). 
Tablica 2. Odnos proizvođača jabuka s otkupljivačima jabuka (distributerima)

\begin{tabular}{|c|c|c|}
\hline & $\begin{array}{l}\text { Srednja } \\
\text { ocjena }\end{array}$ & SD \\
\hline Povjerenje & \multicolumn{2}{|c|}{$\mathrm{N}=\mathbf{5 0}$} \\
\hline Imam povjerenja u našeg otkupljivača (distributera) & 3,70 & ,735 \\
\hline Naš otkupljivač (distributer) je uvijek iskren & 3,64 & ,722 \\
\hline Otkupljivač (distributer) uzima u obzir moje najbolje interese & 3,86 & 857 \\
\hline Otkupljivač (distributer) održava svoja obećanja & 4,00 & ,808 \\
\hline \multicolumn{3}{|l|}{ Ekonomsko zadovoljstvo } \\
\hline $\begin{array}{l}\text { Poslovni odnos s našim otkupljivačem (distributerom) znatno pridonosi } \\
\text { našoj profitabilnosti }\end{array}$ & 3,68 & ,768 \\
\hline $\begin{array}{l}\text { Poslovni odnos s otkupljivačem (distributerom) vrlo je poželjan zbog } \\
\text { dobivanja prihvatljive otkupne cijene jabuka }\end{array}$ & 4,10 & ,953 \\
\hline \multicolumn{3}{|l|}{ Reputacija } \\
\hline $\begin{array}{l}\text { Naš otkupljivač (distributer) dobro je poznat po brizi za svoje poslovne } \\
\text { partnere }\end{array}$ & 4,00 & ,756 \\
\hline Naš otkupljivač (distributer) poznat je po svojoj stručnosti & 3,96 & ,781 \\
\hline Naš otkupljivač (distributer) dobro je poznat po svojoj točnosti & 3,56 & ,812 \\
\hline \multicolumn{3}{|l|}{ Konflikt } \\
\hline S distributerom se slažem u ključnim pitanjima & 2,04 & 727 \\
\hline Naši poslovni interesi se poklapaju s interesima otkupljivača (distributera) & 2,48 & ,931 \\
\hline Ukupno & 3,77 & ,778 \\
\hline
\end{tabular}

Analizirajući suradnju proizvođača s otkupljivačima jabuka (distributerima) utvrđeno je da su proizvođači zadovoljni odnosom s otkupljivačima jabuka (srednja ocjena 3,77). Analizom povjerenja, utvrđeno je da proizvođači jabuka najvišim ocjenjuju doprinos distributera u održanju svojih obećanja (srednja ocjena 4,00), dok najniže ocjenjuju iskrenost distributera u poslovnom odnosu (srednja ocjena 3,64). Povjerenje predstavlja jednu od ključnih varijabli koja utječe na dugoročnost poslovnih odnosa kako s kupcima, tako is dobavljačima te izravno i pozitivno utječe na upravljačke napore u oba smjera u lancu (u smjeru nabave i u smjeru prodaje) (Moorman $i$ sur., 1992). Ako poslovni partneri mogu vjerovati jedan drugome, poslovni odnosi su fleksibilniji čime se smanjuju troškovi poslovanja (Ganesan, 1994) i osigurava konkurentska prednost.

Analizom ekonomskog zadovoljstva koje proizlazi is suradnje s otkupljivačima jabuka, proizvođači višim ocjenama ocjenjuju doprinos distributera u dobivanju pravednije otkupne cijene jabuka (srednja ocjena 4,10 ) u odnosu na doprinos distributera u povećanju njihove profitabilnosti (srednja ocjena 3,68). Pozitivne poslovne prakse, poput veće dobiti, davanja i primanja atraktivnih cijena, manje marže i popusti, pozitivno utječu na ekonomsko zadovoljstvo članova opskrbnih lanaca, stoga i uspješnije opskrbne lance karakterizira viši stupanj ekonomskog zadovoljstva njegovih članova (Geyskens i Steenkamp, 2000).

Pri analizi reputacije, proizvođači visoko vrednuju brigu distributera o njima kao svojim poslovnim partnerima (srednja ocjena 4,00 ) te njihovu stručnost (znaju na koji način se treba ophoditi prema jabukama, što uključuje temperaturni režim prijevoza, način pakiranja kod uskladištenja). Utvrđeno je da proizvođači jabuka najniže ocjenjuju točnost dis- 
tributera, odnosno njihovo nepoštivanje rokova plaćanja (srednja ocjena 3,56).

Proizvođači se najmanje slažu s distributerima u definiranju ključnih pitanja u njihovom poslovnom odnosu kao što su otkupna cijena jabuke, vrijeme berbe (srednja ocjena 2,04). Također, proizvođači jabuka smatraju da se njihovi poslovni interesi u maloj mjeri poklapaju s interesima otkupljivača (srednja ocjena 2,48 ).

\section{Rezultati anketnog ispitivanja s otkupljivačima (distributerima) jabuka} Analiza odnosa otkupljivača s dobavljačima jabuka

$\mathrm{U}$ provedenom istraživanju sudjelovalo je 10 tvrtki specijaliziranih za otkup i prodaju voća. $S$ obzirom na pravno ustrojbeni oblik tvrtki u istraživanju je sudjelovalo osam društava s ograničenom odgovornošću (d.o.o.) (Fruktarija, Agrico Trade, Agrofructus, Bios, Distributivni centar za voće i povrće, Dodir prirode, Setovia voće, Sunce Dubrovnik), jedno Dioničko društvo (d.d.) (Adria), te jedna Zadruga (Zagrebački voćnjaci). Većina otkupljivača (njih 8) navodi kao glavne dobavljače domaće proizvođače jabuka, dok samo dva distributera otkupljuju jabuku iz uvoza. Većina otkupljivača $(\mathrm{N}=9)$ s dobavljačima jabuka ima potpisan kupoprodajni ugovor, bilo da se radi o jabuci ili bilo kojem drugom voću ili povrću. Samo jedna tvrtka nema nikakav ugovorni odnos s dobavljačima jer se njihova suradnja temelji na usmenom dogovoru. U postojećim ugovornim odnosima s dobavljačima jabuka određeni su rokovi isporuke, kvaliteta proizvoda, te način plaćanja. Kvaliteta jabuke se određuje fizikalnim i kemijskim analizama, te klasiranjem ploda na osnovu veličine i boje ploda. Isplata je ugovorena na 30-90 dana od dana otkupa. Način plaćanja je u novcu, bonovima, repromaterijalu i/ili putem kompenzacija, ovisno o tome koji način plaćanja proizvođaču najviše odgovara. Kao glavne probleme u odnosu s dobavljačima jabuke otkupljivači navode: točnost isporuke jabuka (70\%), poštivanje dogovora $(20 \%)$, te kvalitetu jabuka (10\%).

Tablica 3. Odnos otkupljivača (distributera) s dobavljačima jabuka

\begin{tabular}{lcc}
\hline Izjave & Srednja ocjena & SD \\
\hline Pregovaranje s dobavljačima je jednostavan posao & $\mathbf{N = 1 0}$ \\
\hline S dobavljačima imamo prijateljski odnos & 3,10 &, 568 \\
Nemamo izbora nego čvrsto se držati zahtjeva dobavljača & 3,80 &, 422 \\
Dobavljač ima svu moć u našem odnosu & 3,00 &, 568 \\
\hline Ukupno & 2,90 &, 056 \\
\hline
\end{tabular}

Ukupno zadovoljstvo otkupljivača (distributera) odnosom s dobavljačima jabuka je znatno niže (srednja ocjena 3,20 ) u odnosu na obrnut odnos. Rezultati istraživanja pokazali su kako distributeri najvišim vrednuju prijateljski odnos $s$ dobavljačima (srednja ocjena 3,80 ), dok se većina njih osrednje slaže s izjavom da dobavljač ima svu moć u njihovom odnosu (srednja ocjena 2,90) te da nemaju izbora nego čvrsto se držati zahtjeva dobavljača (srednja ocjena 3,00 ). 
Analiza odnosa otkupljivača jabuka (distributera) s trgovcima

Najveći broj otkupljivača kod prodaje jabuka trgovcima susreće se s niskom prodajnom cijenom jabuke (6 distributera), nešto manji broj njih s kvalitetom (3 distributera), a samo jedan s kalibrom - veličinom jabuke.

Tablica 4. Odnos otkupljivača jabuka (distributera) s trgovcima

\begin{tabular}{|c|c|c|}
\hline Izjave & $\begin{array}{l}\text { Srednja ocjena } \\
\qquad \mathrm{N}=10\end{array}$ & SD \\
\hline \multicolumn{3}{|l|}{ Povjerenje } \\
\hline Imam povjerenja u trgovačkog partnera & 2,80 & ,422 \\
\hline Trgovački partner je uvijek iskren & 3,00 & ,000 \\
\hline Trgovački partner uzima u obzir moje najbolje interese & 3,00 & ,471 \\
\hline Trgovački partner održava svoja obećanja & 3,20 & ,919 \\
\hline \multicolumn{3}{|l|}{ Ekonomsko zadovoljstvo } \\
\hline $\begin{array}{l}\text { Odnos s trgovačkim partnerom značajno doprinosi mojoj } \\
\text { profitabilnosti }\end{array}$ & 3,20 & ,422 \\
\hline $\begin{array}{l}\text { Odnos s trgovačkim partnerom vrlo je poželjan zbog dobivanja } \\
\text { prihvatljive prodajne cijene }\end{array}$ & 2,60 & ,516 \\
\hline Ukupno & 3,09 & 0,48 \\
\hline
\end{tabular}

Distributeri imaju nizak stupanj povjerenja u trgovce (srednja ocjena 2,80), ocjenjuju ih osrednje iskrenim u poslovnom odnosu (srednja ocjena zadovoljstva 3,00). Distributeri nisko vrednuju doprinos trgovaca u dobivanju prihvatljive prodajne cijene jabuka. Smatraju da trgovci, posebno supermarketi pri otkupu jabuke imaju previsoke standarde kvalitete.

\section{Zaključak}

Istraživanjem su utvrđene nove spoznaje o stanju i problemima u opskrbnim lancima jabuka. Kod najvećeg broja proizvođača zastupljeniji su neizravni kanali prodaje (distributeri, male privatne voćarne) u odnosu na izravne kanale prodaje (prodaja na gospodarstvu, dostava na kućni prag). Suradnja se temelji na pisanom ugovoru u kojem su ugovoreni rok i način isplata. Način plaćanja može biti u novcu, bonovima, repromaterijalu i/ili putem kompenzacije. Svi ugovori podrazumijevaju strogi rok isporuke, te propisane standarde o kvaliteti jabuke. Najčešći problemi s kojima se susreću proizvođači prilikom prodaje jabuka otkupljivačima su niska otkupna cijena jabuka, način plaćanja te nepoštivanje rokova plaćanja.

Sdruge strane, otkupljivači (distributeri) kao glavne probleme u odnosu s proizvođačima navode nepoštivanje rokova isporuke i kvalitetu jabuka, te poštivanje dogovora. Kod prodaje jabuka trgovcima distributeri kao najvažnije probleme u poslovanju izdvajaju dogovor oko postizanja prihvatljive prodajne cijene te previsoke standarde kvalitete jabuka pri otkupu.

Analizirajući ukupnu suradnju između članova opskrbnog lanca utvrđeno je da su međusobnim odnosima najzadovoljniji proizvođači, a najmanji stupanj zadovoljstva utvrđen je u odnosu između distributera i trgovaca. Prema nalazima istraživanja moguće 
je zaključiti da postoje značajne razlike u percepciji odnosa proizvođača i tržnih posrednika u opskrbnom lancu jabuka.

\section{Implikacije za poslovnu praksu}

Kako bi povećali uspješnost opskrbnih lanaca jabuka potrebno je:

(1) Poslovati u skladu s zakonom u kojem su definirani rokovi ispunjenja novčanih obveza. Za efikasniju naplatu potraživanja i poštivanja rokova plaćanja potrebno je uvesti stroži nadzor i kontrolu provedbe Zakona o financijskom poslovanju i predstečajnoj nagodbi (NN br. 108/12, 144/12, 81/13, 112/13, 71/15, 78/15) u kojem su definirani rokovi ispunjenja novčanih obveza u poslovnim transakcijama između poduzetnika.

(2) Zakonski regulirati nepoštene trgovačke prakse (eksploatacijski ugovori, visoki rabati, kratki rokovi isporuke, povrat neprodane robe). Po uzoru na neke europske zemlje (Francuska, Italija) potrebno je zakonski regulirati nepoštene trgovačke prakse, odnosno smanjiti rabate dobavljača te visinu marži trgovaca na prihvatljivu razinu. Sve do danas najveći napredak postignut je u Francuskoj gdje je pritisak zakonodavstva i provedbenih mjera smanjio rabate dobavljača na prihvatljivu razinu (10 do 15\% umjesto nekadašnjih 50 do $60 \%)$. Rezultat je puno veća transparentnost u raspodjeli koristi u opskrbnom lancu hrane.

(3) Poboljšati komunikaciju i razvijati partnerske odnose temeljene na povjerenju. Razvijanjem partnerskih odnosa temeljenih na povjerenju, pospješila bi se pravodobna izmjena informacija duž lanca što bi omogućilo pouzdanije predviđanje potražnje, ubrzanje toka proizvoda i usluga te podizanje kvalitete cjelokupne distribucije i proizvodnje.

Unatoč malom uzorku ovo istraživanje prvo je takve vrste u Republici Hrvatskoj te stoga predstavlja važan doprinos za znanost i poslovnu praksu, posebice za članove opskrbnog lanca jabuke.

Rezultati istraživanja mogu poslužiti kao informativna podloga istraživačima u području upravljanja opskrbnim lancima prehrambenih proizvoda te svim ispitanicima čije su tvrtke sudjelovale u istraživanju na način da ih potakne da na temelju utvrđenog stanja poduzmu određene mjere za poboljšanje uspješnosti opskrbnih lanaca kojima pripadaju.

\section{Literatura}

Boudahri, F., Sari, Z., Maliki, F., Bennekrouf, M. (2011). Design and optimization of the supply chain of agri-foods: Application distribution network of chicken meat. Communications, IEEE-2011 International Conference on Communications, Computing and Control Applications (CCCA'11), 1-6.

Bourlakis, A., Weightman, P. W. H. (2004). Food Supply Chain Management. Blackwell:Oxford/UK.

Bozarth, C., Handfield, R. B. (2006). Introduction to Operations and Supply Chain Management, Pearson Education, Inc., Upper Sadle River, New Jersey.

Cristopher, M. (2005). Logistics and Supply Chain Management, London: FT Prentice Hall

Duleba, S. (2006). Logistics Trends of the Supply Chains in the Food Industry. Economics and Organization of Enterprise, 57(10), 98-107.

Državni zavod za statistiku RH (2016). Biljna proizvodnja u 2015., Priopćenje broj 1.1.14., 12. svibnja 2016., Zagreb.

Fischer, C., Hartmann, M., Reynolds, N., Leat, P., Revoredo-Giha, C., Henchion, M.,Gracia, A. (2008). Agri-food chain relationships in Europe - empirical evidence and implications for sector competitiveness, European Association of Agricultural Economists, International Congress, August 26-29, 2008, Ghent, Belgium 1-19.

Ganesan, S. (1994). Determinants of long-term orientation in buyer-seller relationships. Journal of Marketing, 58,

Gellynck, X., Molnár, A., Aramyan, L. (2009). Supply chain performance measurement: The case of the traditional food sector in the EU, Ghent University, Faculty of Bioscience Engineering, Department of Agricultural Economics, Division Agro-Food Marketing, Ghent, Belgium.

Krpina, I.,. i suradnici (2004). Voćarstvo, Nakladni zavod Globus, Zagreb

Moorman, C., Deshpande, R., Zaltman, G. (1993). Factors affecting trust in market research relationships. Journal of Marketing, 57, 81-101. 
Par V. i suradnici(2009). Smjernice razvoja voćarstva za razdoblje 2008. - 2013., Agronomski fakultet, Sveučilišta u Zagrebu.

Pupavac, D. (2010). Kooperativna struktura logističkog lanca - preduvjet uklanjanju efekta dvostruke marginalizacije. Montenegrin Journal of Economics. 12 (6), 53 - 59.

Van Lembergen, K., Molnár, A., Gellynck, X. (2009). Relationship measures as indicators of chain performance: The case of the EU traditional food sector, Ghent University, Faculty of Bioscience Engineering Department of Agricultural Economics, Division Agro-Food Marketing, Ghent, Belgium

Woodroof, J. G., Luh, B. S. (1975). Commercial Fruit Processing. The AVI Publishing Company, INC. Westport,. Connecticut.

\title{
Structure of the apple supply chain and analysis of relationship between supply chain members
}

\begin{abstract}
The aim of this paper was to determine the structure and condition of the apple supply chain and to analyze the relationships between chain members. The survey was conducted on a sample of 50 apple producers and 10 buyers (distributors). Distribution of apple to consumers can be undertaken using direct and indirect channels. Direct sales to consumers include selling apples on the family farm and doorstep delivery while indirect sales channels include selling apples to small private fruit store and distributors. Apples from the small private fruit stores are placed directly to the consumers, while the apples from distribution centers are sold to the city markets, small grocery shops near the residence and supermarkets. Analyzing the overall cooperation between supply chain members it can be conclude that producers are the most satisfied stakeholders. The least degree of satisfaction is determined in relationship between distributors and retailers. The most present problems that producers face selling apples are low purchase price, payment procedure and payment deadlines. The most serious problems expressed by buyers (distributors) in relationship with apples producers are unsatisfied delivering accuracy, apples quality, and ignorance of the agreement. The most important problems seen by distributors in relationship with retailers are disagreement to achieve acceptable sales price and too high apples quality standards. According to the findings it can be concluded that there are significant differences between the satisfaction perceptions of relationship between producers and other market intermediaries of the apple supply chain. In order to increase performance of apple supply chain, it is necessary to (1) operate in accordance with the law which define the terms of fulfillment of the financial obligations, (2) legally regulate use of unfair trade practices (exploitative contracts, high rebates, short delivery deadlines, return of unsold goods), (3) improve communication and develop trust-based partnerships. Results can be used as theoretical basis to all respondents those whose companies were participated in the survey in a way to encourage them to based on identified problems take certain measures to improve the performance of their supply chains.
\end{abstract}

Key words: apples market, Croatia, supply chain, relationship 